\title{
A Question of Listening: Nancean Resonance, Return and Relation in Charlie Chaplin
}

\section{Carrie Giunta}

In Jean-Luc Nancy's The Image: Mimesis and Methexis,${ }^{1}$ he considers what makes us say that a portrait lacks only speech. This lack speaks, explains Nancy. A portrait 'speaks to us from its privation of speech.'2 Take the Mona Lisa, for instance. For if the Mona Lisa lacks only speech of her own, this evokes 'something more and other than the sole privation of verbal expression'. The lack, for Nancy, is rather a transport carrying across a Mona Lisa voice, which is not manifested as speech. As her audience, we recognise her voice. What's more, this voice is understood: 'we understand it ... its sense and its truth'. Mona Lisa can make herself understood; yet she does not make herself heard (se fait entendre). Without uttering a word, her voice transports sense.

This bears similarity with listening to the voice of one who is absent. When only a photograph or a film carries the absent person's voice, listening is 'an order other than the order of the visual'. ${ }^{3}$ Voice and speech are not the same thing, Nancy articulates in a mock conversation with Jacques Derrida in 'Vox Clamans in Deserto'. 'Because I know you, I recognised your voice as you were coming toward me, long before I could make out what you were actually saying', Nancy says in addressing Derrida. ${ }^{5}$ This is to say that voice is prior to intelligibility. Voice comes before language.

In order to recognise Derrida's voice, Nancy listens. For Nancy, the main function of listening (l'écoute) is not simply to bear the weight of language as some requirement of intelligibility. Nancy questions a hierarchy of sensible and intelligible forms of listening. His Listening ${ }^{6}$ begins with an indecision: listening can be écouter or entendre - l'écoute or l'entente. ${ }^{7}$ A simple translation into English confounds the two terms, as both may be translated to the same word in English: listening. L'entente is about hearing 
and understanding the spoken word. L'écoute is more than intelligibility of language; it is attention to others.

Nancean listening is the attentiveness that is characteristic of dialogue. According to this theory, listening does not necessarily implicate hearing, nor is it the reverse of speech or hearing. L'écoute, for Nancy, is resonant listening. 'In écouter, the ear goes toward the tension, in entendre, the tension wins over the ear. ${ }^{\prime 8}$ Écouter is to stretch towards sense. This implies a motion towards a tension - and an attention - that re-sounds. ${ }^{9}$ In his work Listening, Nancy calls into question Derrida's specific focus on the immediacy of entendre. I will argue in this chapter, Nancy turns around Derrida's critique of Nancean touching by questioning Derrida on listening.

Attention to another's voice cannot always carry sense. Ovid's fabled Echo ${ }^{10}$ is forbidden the power to speak herself. Her voice is reduced to a single reflection, as she can only repeat the last words of another's speech. She reflects the last words of her star-crossed lover, Narcissus, who is reduced to seeing only his own reflection. Misunderstanding ensues, as Narcissus hears and wrongly understands Echo's words. ${ }^{11}$ Intelligibility fails Echo.

Poor Echo speaks, but lacks the ability to resound another's tonos. Portraiture would be lost to her, as she has not the sonority to stretch towards sense. She could only rebound the words of the spectators in the gallery. A portrait, however speechless, has a voice - a tonos. ${ }^{12}$ As Nancy posits in The Image: Mimesis and Methexis, an unheard tonos is listened to (écouté). The portrait need not speak in order to be listened to and understood:

In its own way, the image then speaks: it speaks on only one plane, at the surface, without referral to a signified ground [un fond signifié]. But on this unique plane, the image makes its own phrasing reverberate - it brings forth that mode of ekphrasis which pushes sound to the surface rather than positing sound upon it..$^{13}$

For Nancy, listening is beyond listening to the signification of sense or language. To regard speech as a privation in the visual arts is a disregard for listening. Nancy's multiple approach to listening will guide the following exploration into cinema's finest listener, Charlie Chaplin.

In Chaplin's time, films came with no soundtrack. They had no shortage of dialogue, however. Actors moved their lips to mime 
speech and films carried copious inter-titles on which viewers could read dialogue lines and expository description. Chaplin's Tramp character is by and large mute. He tends not to employ speech, yet he communicates a range of emotions and thoughts. Chaplin accomplishes this in general through pantomime - gestures, facial expressions, body motion and postures. He relies not on words, but on pantomime to express himself.

During the end of the era of silent films, Chaplin resisted the transition to talking pictures, choosing to keep his character's speechlessness unchanged. Instead, he used audience listening to make himself listened to. In this chapter, I will explore how Chaplin's attention to others as a listening subject is a place of resonance. Through a reading of the final scene of City Lights, ${ }^{14}$ I will consider how, through an interrelationship with the audience and the film, Chaplin refers to himself as other. Using his distinctive powers of attention, Chaplin is a paragon of listening and an archetype for Nancy's thesis on listening.

\section{Visual culture was never silent}

Chaplin's craft hearkens back to an age-old form of storytelling. The first moving images shown on a screen originated in China as early as the Han dynasty. In the ancient art of shadow play, leather puppets pierced with holes projected images onto illuminated screens made of cloth or scrim. The audience watches the puppets' silhouettes come alive on the screen. This works much like the shadow puppetry the prisoners see on the cave wall in Plato's Republic. ${ }^{15}$

In the Republic, Nancy reminds us ${ }^{16}$ voices reverberated, because a cave is a reverberation room as well as a place to throw shadows on the wall. The voices and movements of the people would reverberate in the cave, making audible echoes. Shadow play shows us visual culture was never silent. Cinema audiences have always listened and early cinema was anything but silent. Ever since the early days of motion pictures, cinema has relied on a juxtaposition of visual and sound image. The first films were projected while musical accompanists sat between the audience and the screen, playing alongside the action on the screen. ${ }^{17}$ Early cinema defied language barriers. In the late I920s, the 'talkies revolution' gave rise to an obsession with spoken language and its comprehensibility when synchronised sound eclipsed silent 
cinema. ${ }^{18}$ Synchronised sound works by separating word and image and then marrying them together.

Rather than juxtaposition, Nancean resonance ex-poses the subject. The image enters into resonance with the self. 'One could say here, not that 'it lacks only speech', but rather that 'it makes heard its lack of speech'. 19

\section{A prelude to language}

A recent resurgence of early cinema in popular film narrative recalls this immediacy of word and image that talkies introduced to cinema. Michel Hazanavicius's The Artist (20I I ${ }^{20}$ and Martin Scorsese's Hugo (20II ${ }^{21}$ momentarily renewed interest in silent cinema, ${ }^{22}$ while the minimal synch, no dialogue, animated films of Sylvain Chomet ${ }^{23}$ pay homage to the early work of Chaplin. ${ }^{24}$ For a moment, silent cinema was contemporary again. But popular interest in 'the new silents' has not been sustained.

The Artist illustrates how the transition to the talkies was not an obsession with speech, with technology or with sound, but an obsession with language. The film's downfall, however, is its use of spoken language. Actors move their lips constantly and wordy title cards are frequent. This groundbreaking new silent film still employs copious dialogue. Is contemporary visual culture as fixated with spoken language today as it was in 1927 ?

The bias of logocentric thinking, in which higher value is given to the spoken word, has a tendency to ignore the notion of listening. Philosopher Gemma Corradi Fiumara sees an active move towards non-listening in which 'a culture intoxicated by the effectiveness of its own "saying", is "increasingly incapable of paying heed'. ${ }^{25}$ A culture governed by logos, she holds, is oblivious to what it means to listen.

The origin of truth in Derrida's deconstruction of logocentrism is always assigned to logos. In logocentric thinking, logos is a moment of presence and pure intelligibility. This is when one hears oneself speaking while one is speaking (s'entendre-parler). S'entendre-parler makes speaker and listener immediately present both temporally and spatially, because in this scenario, there is no difference between the speaker and the one speaking. In Speech and Phenomena, ${ }^{26}$ Derrida tends towards entendre over écouter, thus giving privileged status to hearing (understanding) the spoken word, which he claims is the perpetrator in phono-logocentrism. ${ }^{27}$ 
For Derrida, when the voice is heard (understood) in this way, this is consciousness - the experience of pure auto-affection. ${ }^{28}$

By arguing in 'Vox Clamans in Deserto' that the voice is a prelude to language and prior to speech, ${ }^{29}$ is Nancy saying the voice is 'fit for universality'? This fitness for universality occurs in a self-proximity, 'the absolute reduction of space' in which 'no obstacle' meets the voice. ${ }^{30}$ Space is reduced, as the voice does not pass through the world. Proximity between listener and speaker creates self-presence.

Voice, Nancy proposes, is the 'resonant side of speech'. ${ }^{31}$ Voice resonates, thus avoiding its own contradiction. In always addressing the other, the voice can make itself listened to, but not by itself. $^{32}$ If l'écoute is attention to the other, then it is not a matter of listening to oneself as one is speaking, but of listening to the other and to oneself. Nancean listening is a relation to self and between self and other in which the self is also the other.

What becomes apparent in Nancy's multiple senses of listening is Derrida's indifference to l'écoute. In complicating listening as l'écoute and l'entente, Nancy could deconstruct the undervalued position of l'écoute, thus proving the premise of listening's

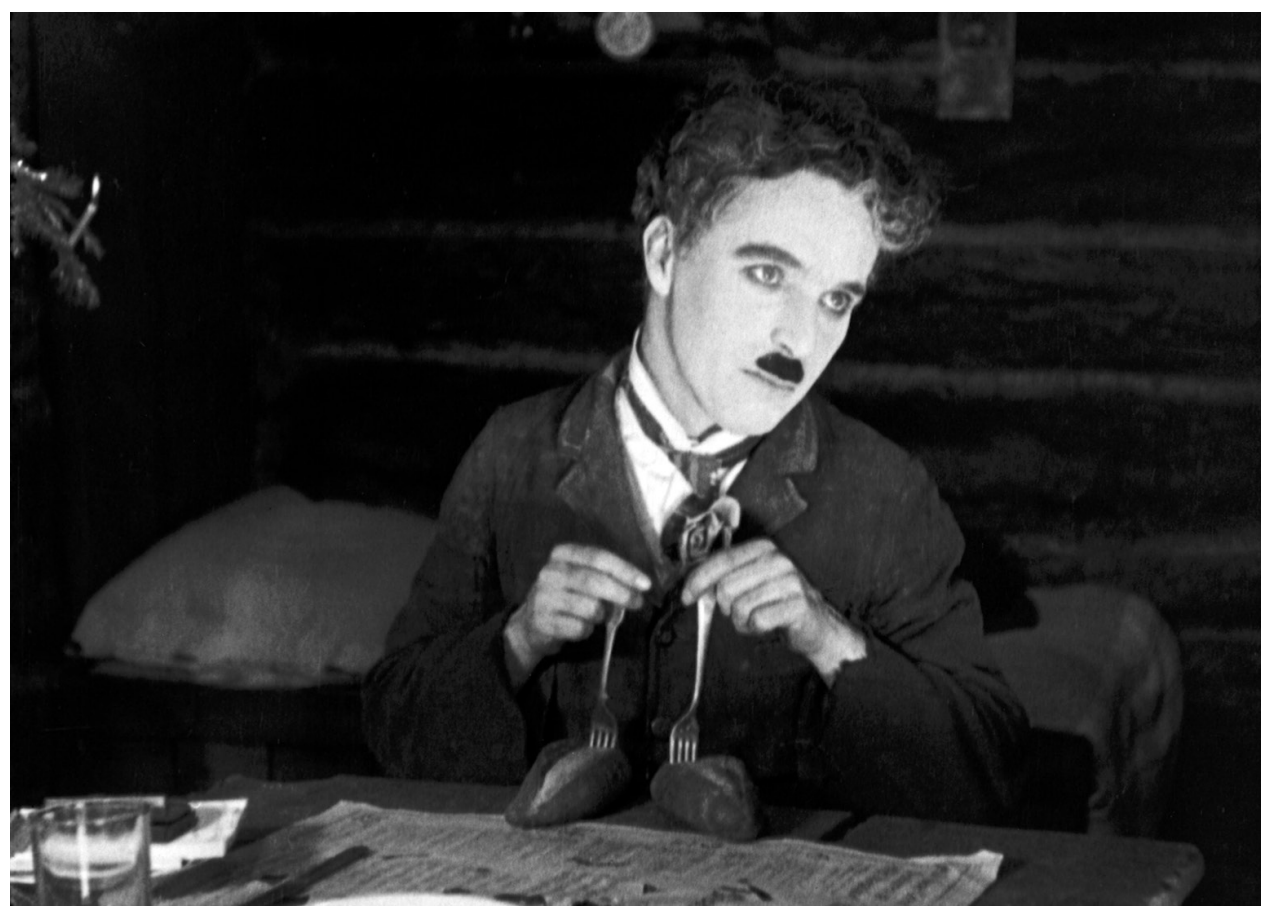

Figure 3.I The Gold Rush (C) Roy Export S.A.S. Scan Courtesy Cineteca di Bologna. 
essentiality to speech. Rather than creating a reversal of speech and listening, or hearing and listening, Nancy reveals a false dichotomy of spoken word (logos) and listening. He poses a question, asking what kind of listening philosophy is capable of. ${ }^{33}$ In asking this, Nancy questions Derrida's neglect of l'écoute.

\section{S'écouter}

The speechless protagonist from silent Chaplin films offers a corpus of texts for investigating questions about l'écoute and l'entente. Chaplin's engagement with the audience does not separate himself and the audience as subject and object. Their dialogue is instead a relation among audience, Chaplin and his self as other. What makes Chaplin unique, as an actor, is his direct access to self and other at the same time.

The Tramp character's unspokenness was hugely successful and overcame language barriers. Chaplin communicates with his audience directly and identifies with the audience by skilfully confiding in the audience via non-verbal dialogue. The large part of his comedy is that relationship he forges with the audience. He builds this relation through the Tramp. I argue Chaplin kept the Tramp silent, refusing to make a talking film because speech would have severed his connection with the audience. It would have obstructed the interrelation between Chaplin and audience.

The problem with bringing the Tramp character into the talkies is with immediacy. The Tramp's voice would have been in absolute proximity with himself speaking. Through his listening, the speechless Tramp's voice passes through a difference via the audience, clearing him of immediate self-presence. The Tramp could not, in a talkie, have this difference with, and interrelationship with the audience because in s'entendre-parler, the Tramp would hear himself speak in self-proximity. This ruins Derrida's argument in Speech and Phenomena. For if a voice keeps silent, thereby eschewing the self-proximity of hearing (understanding)-oneselfspeak (s'entendre-parler), then it is not present to itself.

With non-verbal, speechless gestures enough to rival the Mona Lisa's arch facial expression, can Chaplin listen the same way she listens?

Chaplin manages to make himself understood (se fait entendre) as he makes himself listened to (se fait écouter). ${ }^{34}$ With each silent movement, he stretches towards sonority, returning a voice that 
has nothing to do with speech or sound, but is inclined towards the opening of sense. Chaplin listens to himself-as-other, and by transmitting this in his films, makes his listening listened to. This is his s'écouter.

To illustrate what s'écouter means I will examine Chaplin's attention to others. In the Tramp character there is difference between the audience and Chaplin's self as other. There is no immediate presence or presence to self in this difference because there is temporal and spatial difference, unlike in s'entendreparler, which is immediate self-presence between self and speaker. The voice of the other is already shared within the Tramp's own voice. This presence of the other means the Tramp's voice is not in absolute proximity to Chaplin or the other. Chaplin listens not as a hearing-oneself-speak form of auto-affection, but his listeningto-himself decentres difference. With this difference, immediate self-presence is inhibited both as a spatial presence and as a temporal one. In short, the Tramp character is present to his self neither temporally nor spatially in s'écouter.

This is evident when the Tramp partakes in a silent dialogue with objects. In the 'Oceana Roll', a scene also known as 'the dance of the dinner rolls' in The Gold Rush, ${ }^{35}$ the action takes place on New Year's Eve. Chaplin's character has prepared a special meal for invited dinner guests, including love interest Georgia. However, his guests have forgotten about the invitation, leaving the Tramp crestfallen and alone at the dinner table. While seated there, he imagines that he is entertaining his guests and they are dancing. He enacts his fantasy dance using two forks stabbed into two bread rolls. Manipulating the forks with his hands, the bread rolls approximate his oversized clown shoes and the forks function as legs. Though his hand movements are simple, Chaplin's dreamy facial expressions animate the bread rolls' simple 'steps'. He does not merely play with his food; by appropriating objects from the dinner table through which he converses, he makes his daydream listened to via a voice otherwise conveyed through his feet.

By way of the other, he listens to himself through a movement of resonance. This movement is s'écouter in that Chaplin listens to himself resounding. Nancy envisions a place where vibrations resound as their natural frequencies are combined with other vibrations. Nancy treats the body as a vibrating system, in which sense opens up, amplifies and extends. 


\section{A place of resonance}

Who is listening for Nancy is a place of resonance. Listening as s'écouter by way of the movement of Nancean resonance is not an absence to speech's presence. It attends to the other and to the self as other. This theory of resonance is key to Nancy's argument in Listening because resonance gives alterity to s'écouter. Resonance makes the subject as other because it refers back to a self as other. Whereas Echo loses her place of resonance, and as a result, cannot listen, resonance puts the other in Chaplin.

Practically, resonance is when a frequency is applied at or near the natural frequency of a vibrating system and forces vibrations at the frequency of the one applied, resulting in vibrations of higher amplitude and longer duration. This means a vibrating system will pick out tones that correspond to its natural frequencies and exaggerate those frequencies. For instance, most stringed instruments have a hollow wooden case filled with nothing but air. The air in the box, forced into vibration by the string, emits vibrations similar to those of the string. As string tension causes the air inside the violin's wooden body to vibrate, this movement of vibrations amplifies volume (spatialisation) and prolongs duration (temporalisation) of the vibrations. ${ }^{36}$

The movement of resonance is a spacing movement without interval. It is an extension in space and a lengthening in time. Vibrations, however, in order to change in intensity, and in order to be listened to, undergo a back-turning (rebroussement), referring back (renvoi) movement. Chaplin resounds as he listens to himself (s'écoute). Then, turning back, he resounds further away. ${ }^{37}$ Chaplin spatialises in his resounding, though not via an interval or by expanding. He extends within the available space of his body and fills that space. The violin, out of whose body resonance resounds, illustrates this type of extension. Resonance extends first within the space of the violin, causing the intensified vibrations to then leave the violin's body. Vibrations do not separate; they intensify. Resonance is a spacing movement that does not create an interval connecting or separating disparate elements.

In a place of resonance, a subject returns to or refers back to its self as another subject and not as self-presence. ${ }^{38}$ The return is the space of a self, and not presence to the self. Therefore, listening is a referring, and not a deferring. This improves on Nancy's discussion in Corpus, about the impenetrability of bodies: 'Two bodies can't 
occupy the same place simultaneously ... I can't speak from where you listen, and you can't hear [listen] from where I speak ... ${ }^{39}$ In a place of resonance, a subject refers back to its self as other, and not as two bodies. Nancy thinks of the listening subject not as a subject, except as the place of resonance, where vibrations resound.

The subject - the place of resonance - is the part of the body that is listening as a means of approaching the self..$^{40}$ For Nancy, the self is a referral. As a subject, Chaplin's self is other, another subject and not another self or a split self. He and audience are not separated in a Cartesian sense. Chaplin becomes a subject through s'écouter, speaking as himself and as audience. He resounds as the audience - an other, but not an object. His dialogue with the audience is between a self and a 'you'. It is not an inner dialogue or a split self. In Nancy's theory of listening, the subject that is listening touches itself as a 'means of approaching the self'. ${ }^{41}$ In listening, a subject occurs in the space or resonance of the referral. It touches itself (il se touche).

\section{Se toucher toi}

As Nancy's s'écouter is a means of questioning the logocentric thinking in Derrida's deconstruction of logocentrism, Derrida discusses a similar phrase, se toucher toi, in his critique questioning the immediacy in Nancy's theory of touching. Derrida deems logocentrism a bias in the tradition of a metaphysics of presence where word is primary. It follows that in the metaphysics of presence of touching, touch is primary. Derrida speaks about se toucher toi in which the link between the 'you' and the self is indissociable.

On Touching - Jean-Luc Nancy ${ }^{42}$ is Derrida's deconstruction of haptocentrism or a privileging of the figure of touch, which he proposes forms a pattern in many traditions of thought. Haptocentric thinking deems touch as a centre or moment of presence. The whole tradition of European philosophy, Derrida argues, privileges this haptology or figure of touch based in Christian theology. ${ }^{43}$ In On Touching, Derrida asserts Nancy bases his figure of touch on Christian theology, which emphasises the distance and discontinuity between touch and touched. ${ }^{44}$ Derrida questions the possibility of immediacy between touching and what is touched. This implies unity, immediacy and continuity between touching and the touched, despite Nancy's claim to think of touch as fragmented and discontinuous: ${ }^{45}$ 
Nancy seems to break away from haptocentrist metaphysics, or at least to distance himself from it. His discourse about touch is neither intuitionistic nor continuistic, homogenistic, or indivisibilistic. What it first recalls is sharing, parting, partitioning, and discontinuity, interruption, caesura - in a word, syncope.

Nancy wants a touching that is independent from haptocentrist metaphysics, 'part of the great tradition that accords an absolute privilege to touch and does not let itself be encroached upon by the possibility ... of any vicariousness of the senses'. ${ }^{46}$ This contact through interruption is for Derrida, manifested in a self-touching auto-affection that interrupts itself as itself. In this way, touch is not only contact; it is also non-contact.

For Nancy, touching is outside of or in excess of a haptocentric tradition. Derrida argues touching is a self-interrupting contact that is more of a self-touching (se toucher) that adheres to a haptocentric tradition indicating continuity, unity and immediacy. ${ }^{47}$

It is a certain way of self-touching without touching, or touching oneself and interrupting the contact, but a contact, a tactility, that nevertheless succeeds in interrupting itself. It succeeds in setting up contact, in setting itself up as contact, in thus touching itself in interrupting itself, at the moment when it's suspending - or even forbidding or abstaining - itself, to such a point that it's holding its breath, so as to give itself, still, within the syncope, the pleasure of which it is depriving itself.

The material, proximate, relational contact is broken by a noncontact in which a self interrupts itself as itself and not as some other. This special type of interruption, Derrida claims, is actually a unity and continuity perpetuated in auto-affection. Therefore, Nancy's questioning of touch is a certain loyalty to the very tradition of haptocentrism that he distances himself from. ${ }^{48}$ Derrida asserts that Nancy bases his figure of touch on Christian theology, which emphasises the distance and discontinuity between touch and touched. Derrida's idea of touching has temporal and spatial difference and is not auto-affection.

The difficulty of presence in the figure of touch ${ }^{49}$ is that just as sense does not sense itself, for Derrida 'touching' touches on the 'untouchable'. Thus, touching is both touchable and untouchable - it is an 'untouchable touchable'. ${ }^{50} \mathrm{He}$ points to the double 
meaning of the phrase il se touche, due to its variable reflexivity and reciprocality. In il se touche, the phrase could either mean he/ it self-touches it/himself or, it/he is touchable by an other. ${ }^{51}$ The untranslatable original title of the text, Le Toucher, Jean-Luc Nancy, ${ }^{52}$ has a double meaning. Le toucher means both 'touch' and 'to touch him'. Se toucher, however, is more complex. Translator Christine Irizarry explains se toucher can work in either reflexive or reciprocal modes..$^{53}$ It 'can turn the subject toward itself ... or toward the other, according to a reciprocity that is easier to say than to attain'. ${ }^{54}$ In short, this grammatical aspect 'puts transitivity in reflexivity'. 55

This critique of haptocentrism emphasises separation and difference. Derrida uses the phrase se toucher toi not as a reflexive gesture, but as a phrase of unity and dissymmetry that also has transitivity. Se toucher to $i$ has two meanings: 'self-touching-you' and 'to self-touch you'. ${ }^{56}$ In se toucher toi, touching is in contact with oneself as well as with the other. In order to be touched this way, 'I have to touch myself.' 'When I speak to you, I touch you, and you touch me when I hear you, from however far off it comes to me ... ${ }^{57}$ Derrida sees the 'self' and the 'you' as equally 'indispensable', suggesting connection or relation rather than rupture or separation. ${ }^{58}$ In this scenario, the self and the 'you' are not the same and not in symmetry. Self and 'you' refer to two different people together in dissymmetry.

Se toucher toi cannot work in reflexive mode. To do so would be to split the self into two selves. In other words, an attempt to form a reflexive version of se toucher toi would produce 'to selftouch yourself' or 'self-touching yourself'. The 'you' and the 'self', however, are not interchangeable. ${ }^{59}$

The 'you' and the 'self' in se toucher toi are not self-present subjects, but they do have potential duality. Se toucher toi, therefore, is both immediacy and interruption at the same time, where 'at the same time' means indissociably. The gap and the interrupting movement of touching are indissociable; making an immediacy possible that is not based on time.

The non-reflexive basis of se toucher toi provides a different expression of Chaplin's interaction with himself as other (s'écouter). S'écouter could denote a self-reflexivity that implies an interior dialogue between Chaplin and himself. Chaplin's dialogue, however, does not occur by means of a splitting of his Tramp self into a self and 'my other self'. Alternatively, Chaplin's 
self is in dialogue not with another self, but instead, with a 'you'. Derrida explains the 'you' is not susceptible to a relation to self or to self-touching. While the self and the 'you' remain balanced in se toucher toi, the phrase conveys dissymmetry by maintaining first and second person pronouns. 'You' stays in the second person and does not change to the first person. ${ }^{60}$ Se toucher toi reveals a self that is as crucial as the 'you'.

Like s'écouter, se toucher toi shares a commonality with the turning back movement that vibrations undergo when a sonorous body resounds. In a similar motion to the oscillation of resonance, se toucher toi goes back and forth between the self and the 'you'. 'When I speak to you, I touch you.' 'You touch me when I hear you. ${ }^{61}$ This supports the argument that self and 'you' are not opposed, but linked. If the self were split, it would undermine the movement of resonance because a divided self, as subject and object, prevents the referring back of resonance.

\section{What happens when the Tramp speaks?}

This self that Chaplin approaches touches its self as other. His touching is reciprocal without being an auto-affection. There is a kind of mutual touching that occurs in the last scene of the film City Lights. The scene is known as one of Chaplin's most sentimental 'that cliché that so many critics use to avoid dealing with Chaplin's actual complexity'. ${ }^{62}$ By seeing beyond the sentimentality of this scene, we may understand how the scene addresses Derrida's question in On Touching: 'What happens when our eyes touch'?63

In this scene, the Flower Girl, who was blind up until this point in the film, finally sees the Tramp with her newfound vision. Before screen testing Virginia Cherrill, who plays the Flower Girl in City Lights, Chaplin had difficulty finding an actress who could act blind without contorting her face. Cherrill's ability to 'look inwardly' is what got her the part. 'To my surprise she had the faculty of looking blind. I instructed her to look at me but to look inwardly and not to see me, and she could do it. ${ }^{36}$

The Flower Girl looks at the Tramp, yet she does not recognise him. Throughout the film, she believed that the benefactor who funded the operation that restored her sight was a millionaire. Here, she discovers that the Tramp is in fact the person that cared for her when she was ill and who funded the operation that gave her the ability to lift herself out of poverty. In the denouement, the 
Flower Girl and the Tramp meet each other again through a plate glass window after the Tramp's release from prison. She looks out of the shop window at the Tramp and laughs. She looks out with two eyes, as she could never have done before when she was blind. The Tramp, looking in, sees her.

When she was blind, the Flower Girl recognised the Tramp by touch. She sees him for the first time when she touches his hand because sight for her when she knew him before was touch. What happens when their eyes touch is an interruption to touching. To touch without touching, 'to embrace eyes', se toucher toi, Derrida says, is 'a break with immediacy'. ${ }^{65}$ It interrupts self-presence, as the Tramp no longer sets his eyes on a blind flower girl who looks inwardly. The other is 'touched by your eyes' without touching itself or being touched. ${ }^{66}$

'Nancy wants to go back before sight ...' says Derrida towards the end of On Touching. ${ }^{67}$ Similarly, Chaplin wants to go back before cinema. In City Lights, Chaplin directly addresses the overhaul of the cinema industry, which by the time of City Lights's release was at the peak of the 'talkies revolution', and at the twilight of silent cinema. ${ }^{68}$ City Lights was the next to last appearance of the Tramp. Chaplin resisted the change from silent films to talkies because the talkies would institute a change in the way in which his work would be listened to. To go back before cinema is to ask the question, 'what happens when the Tramp speaks'? In the first chapter of On Touching, Derrida extends the question: 'When our eyes touch, is it day or is it night'? When the Tramp speaks, is it day or is it night; is it l'écoute or is it l'entente? ${ }^{69}$ Mutually touched by your eyes, Chaplin manages to balance the harmonious pair. He makes himself understood (se fait entendre) and he makes himself listened to (se fait écouter) without actually speaking.

In his critique that Nancy offers no relation or mediation between a presenting and the thing that is presented, except from itself, Derrida asks if Nancean touching implies unity, immediacy and continuity between touching and the touched despite Nancy's claim to think of touch as fragmented and discontinuous. Nancy's theory in which resonance is non-presence that is also immediacy improves on his thesis on touching that Derrida deems haptocentrism. As Derrida points to a metaphysics of presence of touching in which touch is primary, Nancy brings attention to the neglect for l'écoute and emphasis on l'entente in Derrida's deconstruction 
of logocentrism that claims speech as primary. In short, Nancy turns around Derrida's critique of touching by questioning Derrida on listening.

\section{More than a privation of speech}

How does visual culture listen? When the former silent film star, Norma Desmond, says in Sunset Boulevard:: 'We didn't need dialogue. We had faces.', ${ }^{70}$ she means 'the tonos of the image' resounds without words. The Mona Lisa can even resound without being seen. After she was stolen from the Louvre in I9I I, crowds gathered to stare at the empty space on a blank wall where the painting once hung on display. Many of the people who queued to see the empty space had never visited the Louvre before and had never seen the painting in the first place. ${ }^{71}$ She became more popular while in exile. 'That which resonates in this case is nothing other than painting itself. ${ }^{72}$ Does Mona Lisa listen as a place of Nancean resonance, as Chaplin listens?

Moving in resonance, Chaplin, through his direct engagement with the audience, attends to and answers the demand of the other. He listens to the audience, makes his listening listened to (s'écouter) and at the same time makes himself understood (se fait entendre). Chaplin's connection with himself as other and audience as other is a mutuus contactus. Se toucher toi, like s'écouter, breaks with immediacy when it interrupts self-presence. A talking Tramp character would create auto-affection, which would interfere with his interrelation with the audience. It would ruin his difference and make him immediately present to himself.

Audiences coming to silent cinema for the first time may experience similar powers of attention. If a new silent cinema resounds without words, its lack of speech can be listened to.

\section{Notes}

I. Jean-Luc Nancy, 'The Image: Mimesis and Methexis', in this volume.

2. Ibid.

3. Ibid.

4. Jean-Luc Nancy, Multiple Arts: The Muses II, trans. Simon Sparks (Stanford: Stanford University Press, 2006), 38-49.

5. Nancy, Multiple Arts, 38. 
6. First published in 2002 in Paris as À L'écoute. Jean-Luc, Nancy, $\grave{A}$ L'écoute (Paris: Gallilé, 2002).

7. 'La mince indecision tranchante . . . entre écoute et entente' 'Entre une tension et une adéquation', where adéquation means 'perfect adaptation'. This could imply that entendre means to adapt to the circumstances in order to grasp some meaning. Nancy, À L'écoute, I 2-I3.

8. Jean-Luc Nancy, Listening, trans. Charlotte Mandell (New York: Fordham University Press, 2007), I, 69.

9. Entendre and entente share the Latin root, ten, 'to stretch, stretch out, distend, extend'. The root 'to stretch' implies that listening has potential to expand and create space for something else.

Io. The fable of Echo and Narcissus in Ovid, in which Echo is doomed by an angry goddess never to speak for herself again. Ovid, Ovid's Metamorphoses in Fifteen Books (Cambridge: Chadwyck-Healey, I992).

I I. Gayatri Chakravorty Spivak, 'Echo', in The Spivak Reader, ed. Donna Landry and Gerald MacLean (London and New York: Routledge, I996), I83-5. In Spivak's reading, a difference and a deferment occur when Echo speaks independently of Narcissus's intention.

I2. Nancy, 'The Image', in this volume.

I3. Ibid.

I4. Charlie Chaplin, City Lights, film, directed by Charlie Chaplin (I93 I, UK: Warner Home Video UK, 2003), DVD.

I 5. 'Just as puppet showmen have screens in front of them at which they work their puppets.' Plato, Republic, 5 I4a, trans. G. M. A. Grube (Indianapolis: Hackett Publishing Company, I992).

I6. Plato, Republic, 5 I 5c. Nancy, Listening, 75. Nancy states precisely the echo of voices in the cave is forgotten due to Plato's heavy emphasis on vision and light.

I7. Carrie Giunta, review of Beyond the Soundtrack: representing music in cinema, ed. Daniel Goldmark et al., Historical Journal of Film, Radio and Television 30 (2010): 132-3.

I8. Laura Mulvey, 'Cinema Sync Sound and Europe r929: Reflections on Coincidence', in Soundscape: The School of Sound Lectures I 998-200 I, ed. Larry Sider et al. (London: Wallflower, 2003), 23-4.

I9. Nancy, 'The Image', in this volume.

20. Michel Hazanavicius, The Artist, film, directed by Michel Hazanavicius (20I I, USA: The Weinstein Company, $201 \mathrm{I}$ ).

2I. Martin Scorsese, Hugo, film, directed by Martin Scorsese (20I I, USA: GK Films, 2OII), DVD. 
22. Paul Flaig and Katherine Groo, New Silent Cinema (New York and Abingdon: Routledge, 2015).

23. Sylvain Chomet, L'illusionniste, film, directed by Sylvain Chomet (France: Pathé, 2010) DVD. Sylvain Chomet, Les triplettes de Belleville, film, directed by Sylvain Chomet (S. France: Celluloid Dreams, 2003) DVD. Sylvain Chomet, La vieille dame et les pigeons, film, directed by Sylvain Chomet (S. France: GFC, I998) DVD.

24. Sylvain Chomet's animation films have been inspired by Chaplin and by the silent comedy work of I960s film-maker and actor Jacques Tati.

25. Gemma Corradi Fiumara, The Other Side of Language: A philosophy of listening (London: Routledge, I990), 8, I7, 23, 29, 3 I. Fiumara attributes the tendency in Western philosophy to ignore the notion of listening to logocentric thinking, a bias in which higher value is given to the spoken word.

26. Jacques Derrida, Speech and Phenomena: And Other Essays on Husserl's Theory of Signs, trans. David B. Allison (Evanston: Northwestern University Press, 1973). This is Derrida's critique of logocentric thinking as hearing-oneself-speak (s'entendre-parler).

27. Phonocentrism prioritises speech or voice (phone) and debases writing.

28. Jacques Derrida, Of Grammatology, trans. Gayatri Chakravorty Spivak (Baltimore and London: The Johns Hopkins University Press, I997), 3, 20, 98.

29. Nancy, Multiple Arts, 39, 4I.

30. Nancy, Multiple Arts, 79.

3 I. Nancy, Multiple Arts, 47.

32. Derrida, Speech and Phenomena, 86. This is consonant with Derrida's further argument that 'Hearing oneself speak is not the inwardness of an inside that is closed in upon itself; it is the irreducible openness in the inside ...' This openness is made possible by time.

33. Nancy, Listening, I. Nancy asks: Can philosophy listen as l'écoute or as l'entente?

34. In: Jean-Luc Nancy, 'Ascoltando', foreword to Listen: A history of our ears, by Peter Szendy, ix-xiii, I46, trans. Charlotte Mandell (New York: Fordham University Press, 2008), Nancy discusses a reflexive listening in which he believes music listens to itself ( $i l$ s'écoute), setting the stage for Szendy's question: 'Can one make a listening listened to?' 
35. Charlie Chaplin, The Gold Rush, film, directed by Charlie Chaplin (I925, UK: Warner Home Video UK, 2003), DVD.

36. Firth et al., Wray, Waves and Vibrations (Middlesex: Penguin Education, I973), 237-8. Edward Gick Richardson, Sound: A physical text-book (London: Edward Arnold \& Co., I 947), 56, 76, 98.

37. Nancy, Listening, 35 .

38. Nancy, Listening, 8, I 2-I6.

39. Nancy Corpus, trans. Richard A. Rand (New York: Fordham University Press, 2008), 56-7. Richard A. Rand translates écouter as 'hear'. Mais je ne peux pas parler d'où vous écoutez, ni vous, écouter d'où je parle - ni chacun d'entre nous écouter d'où il parle (et se parle).

40. Nancy, Listening, 8-9, I 2-I3.

4I. Nancy, Listening, 8-I3.

42. Jacques Derrida, On Touching - Jean-Luc Nancy, trans. Christine Irizarry, (Stanford: Stanford University Press, 2005).

43. Derrida, On Touching, 243.

44. Jack Reynolds, Merleau-Ponty and Derrida: Intertwining Embodiment and Alterity, (Athens: Ohio University Press, 2004), 57-8. Jack Reynolds, however, offers a reading of Maurice MerleauPonty's work on touching that considers wrong Derrida's claim that touching is a metaphysics of presence, by asserting touching is a nondualistic difference between self and other.

45. Derrida, On Touching, I 56.

46. Ibid., 4I.

47. Ibid., 38 .

48. Ibid., I28. Ian James, The Fragmentary Demand: An introduction to the philosophy of Jean-Luc Nancy (Stanford: Stanford University Press, 2006), I20, I30.

49. James, Fragmentary Demand, 47.

50. Derrida, On Touching, I 33 .

5 I. Ibid., 6, I 8, 34 .

52. Jacques Derrida, Le toucher, Jean-Luc Nancy (Paris: Éditions Galilée, 2000).

53. Christine Irizarry, translator's note, On Touching - Jean-Luc Nancy by Jacques Derrida (Stanford: Stanford University Press, 2005), 3 I $7-\mathrm{I} 8$.

54. Derrida, On Touching, ıо8. See also: Jacques Derrida, 'Le Toucher: Touch/to touch him'. Paragraph I6 (I993): I 52.

55. Derrida, On Touching, 29 I.

56. Ibid., 34 . 
$72 \quad$ Nancy and Visual Culture

57. Ibid., 29I.

58. Ibid., I I 5, 29 I.

59. Ibid., $28 \mathrm{I}$.

6o. Ibid., $28 \mathrm{I}-2$.

6I. Ibid., 29I.

62. Tom Gunning, 'Chaplin and the body of modernity', Early Popular Visual Culture 8 (2010): 240.

63. Derrida, On Touching, 28I.

64. Charles Chaplin, My Autobiography (London: Penguin, 2003), 323.

65. Ibid., 292-3.

66. Derrida, On Touching, 283.

67. Ibid., 305 .

68. However, Yasujirō Ozu, Dziga Vertov, F. W. Murnau, and Charlie Chaplin all released non-talking films in I93 I. In January I93 I, City Lights was released, a film with no dialogue and few sounds.

69. Derrida, On Touching, 2. Jean-Luc Nancy, 'Le Toucher: Touch/to touch him', Paragraph I6 (1993): I 22-57.

70. Billy Wilder, Sunset Blvd, film, directed by Billy Wilder (1950, USA: Paramount Pictures, 2003), DVD.

71. Darian Leader, Stealing the Mona Lisa: what art stops us from seeing (New York: Counterpoint, 2002).

72. Nancy, 'The Image', in this volume. 